\title{
Rainwater Use for Vertical Greenery Systems: Development of a Conceptual Model for a Better Understanding of Processes and Influencing Factors
}

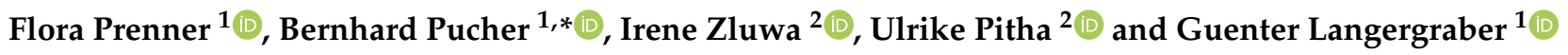 \\ 1 Institute of Sanitary Engineering and Water Pollution Control, University of Natural Resources and Life \\ Sciences, Vienna (BOKU), Muthgasse 18, 1190 Vienna, Austria; flora.prenner@boku.ac.at (F.P.); \\ guenter.langergraber@boku.ac.at (G.L.) \\ 2 Institute of Soil Bioengineering and Landscape Construction, University of Natural Resources and Life \\ Sciences, Vienna (BOKU), Peter-Jordan-Straße 82, 1190 Vienna, Austria; irene.zluwa@boku.ac.at (I.Z.); \\ ulrike.pitha@boku.ac.at (U.P.) \\ * Correspondence: bernhard.pucher@boku.ac.at
}

\section{check for}

updates

Citation: Prenner, F.; Pucher, B.; Zluwa, I.; Pitha, U.; Langergraber, G. Rainwater Use for Vertical Greenery Systems: Development of a Conceptual Model for a Better Understanding of Processes and Influencing Factors. Water 2021, 13, 1860. https://doi.org/10.3390/ w13131860

Academic Editor: Richard

C. Smardon

Received: 7 June 2021

Accepted: 29 June 2021

Published: 3 July 2021

Publisher's Note: MDPI stays neutral with regard to jurisdictional claims in published maps and institutional affiliations.

Copyright: (c) 2021 by the authors. Licensee MDPI, Basel, Switzerland. This article is an open access article distributed under the terms and conditions of the Creative Commons Attribution (CC BY) license (https:// creativecommons.org/licenses/by/ $4.0 /)$.

\begin{abstract}
Vertical greenery systems (VGS) are promoted as a nature-based solution to mitigate the urban heat island effect. In order to ensure the long-term provision of this function, sufficiently available irrigation water is the key element. Currently, potable water is one of the main resources for irrigation of VGS. While rainwater is often mentioned as an alternative, only a few studies investigate the actual application of rainwater for irrigation. In this study a conceptual model is developed to present the processes and influencing factors for a holistic investigation of rainwater use for irrigation. In this model, five sub-modules are identified: the atmospheric, hydraulic, quality, rainwater harvesting and VGS sub-module. The conceptual model depicts which processes and influencing factors are involved in the water demand of VGS. Thus, the conceptual model supports a holistic understanding of the interrelations between the identified sub-modules and their relevance for VGS irrigation with harvested rainwater. The results of this study support the implementation of rainwater harvesting as a sustainable resource for VGS irrigation.
\end{abstract}

Keywords: vertical greenery systems; rainwater harvesting; conceptual model

\section{Introduction}

The shift from grey to green infrastructure using nature-based solutions $(\mathrm{NbS})$ to address the urban challenges of the 21st century is ongoing. Changes in precipitation patterns and volumes pressure the static piped drainage systems and increases the risk of flooding [1]. Urbanization and the sealing of surfaces continuously add to this issue and act as amplifiers. In addition, sealed areas increase the urban heat island (UHI) effect, which influences the health of the inhabitants and is proven to cause fatalities $[2,3]$.

The implementation of $\mathrm{NbS}$ is restricted by the available space at ground level. Therefore, the implementation of green roofs and vertical greenery systems (VGS) on the building envelope has proven to be a practical measure [4,5]. As the facade of a building has an overall higher area compared to the roof, VGS are identified of having a high potential for UHI mitigation and building energy saving [6-10].

While the energy saving capabilities can be accounted for the shade effect, as well as the insulation and wind blocking due to structure and vegetation, only the cooling effect is directly related to the available water for plant transpiration [11,12]. Currently, one of the main resources of irrigation water is potable water. This is a comfortable practice based on an existing infrastructure which adds to the problem of resource depletion. While potable water is transported towards the cities, rainwater and wastewater are discharged and leaves the city. Within a shift towards a circular economy in the water sector $[13,14]$, the practices are slowly changing. For wastewater reuse, greywater, which excludes the 
wastewater from toilets, is mainly part of research studies using VGS for treatment [15-18]. Shi et al. [19] recommend the use of rainwater instead of potable water to cover green space water demand. Depending on the scale, rainwater harvesting can include only the roof area as well as the road run-off for bigger applications [20]. While the use of rainwater is already applied for green roofs [21-23], studies investigating rainwater use for VGS are scarce [24] or combined with greywater use to overcome long dry periods and secures the water supply for the vegetation [25].

In order to provide the needed actual water demand for a certain plant species, several factors must be recognized. Based on the season and the exposition of the VGS, radiation intensity and air temperature can be different. The used plant growing media (PGM), including both soil substrates and alternative growing media (e.g., felt systems), is also influenced by these atmospheric conditions. For rainwater harvesting, the run-off area and its properties are of importance in influencing the tank size and material. Depending on the accumulated pollutants, treatment might be necessary.

The aim of this paper is to establish a holistic understanding of the processes involved when using rainwater only irrigation for VGS. Currently, these processes and their influencing factors on one another are not fully depicted in literature. Therefore, a conceptual model is developed. The results of this paper fosters the understanding of the interplay between VGS, rainwater harvesting $(\mathrm{RWH})$ and the urban surrounding as an interdisciplinary matter. Thus, the conceptual model helps to promote an integrative approach when planning RWH as a sustainable resource for the irrigation of VGS.

\section{Materials and Methods}

The development of the conceptual model was performed in the following three steps.

\subsection{Step 1-Identification of Processes and Influencing Factors for Irrigation of VGS}

A literature research was conducted to identify the processes and influencing factors involved to describe the irrigation of VGS with rainwater. Processes are hydrological processes and can be of a physical or chemical nature. Influencing factors are characteristics of the sub-modules, which have an influence on the conditions in other sub-modules.

The literature research was carried out in the Scopus and Web of Science electronic databases. The search terms were chosen to identify the papers published on different types of VGS. The search string used to search within the title, abstract and keywords of papers are listed as follows: "green AND wall* OR living AND wall* OR green AND fa?ades $*$. The results were limited to review papers to obtain an overview of the state-ofthe-art in the research field. Afterwards, the remaining publications (excluding abstract and references) were searched for keywords to extract information about the involved processes and influencing factors. The following keywords were chosen: "water", "irrigation", "UHI" and "cooling". Results from this keyword search in the review papers were identified as relevant if the content was related to the water use of VGS or the water provision by RWH system. Lastly, knowledge gaps in the review papers were identified and filled with literature from other disciplines, mainly from research on green roofs and RWH. These papers were also searched for the above-mentioned keywords to organize the content and their contributions to the conceptual model.

\subsection{Step 2-Definition of Sub-Modules}

Identified processes and influencing factors were assigned to a class according to their position in the water pathway from rainfall to irrigation of VGS. A pre-classification was performed with "atmospheric processes", "rainwater harvesting" and "VGS irrigation". Subsequently, classes (later called sub-modules) containing a lot of information were further divided to allow more detail. Specifically, the sub-module "rainwater harvesting" was further divided into the sub-modules "hydraulic", "quality" and "RWH". This process resulted in a total of five sub-modules in the conceptual model: tmosphere, hydraulic, quality, RWH and VGS. 


\subsection{Step 3-Definition of Boundary Conditions}

After the conceptual model was developed, the boundary conditions were defined. The boundary conditions for the calculation of water demand are described for the two main VGS types: Living walls and green facades, based on the nomenclature presented by Bustami et al. (2018) [26]. Living walls are greenery systems, where plants are grown in planter boxes directly attached to the facade and are not reliant on rooting space on the ground. Green facades are greenery systems, which are grown on the building facade. Green facades can be planted in soil or in planter boxes and therefore rely on ground space [26]. Based on the design characteristics of the VGS types (arrangement of the modules, presence of drainage openings and overflow possibilities), the potential hydrological processes are identified to calculate the water demand for each VGS type.

\section{Results}

\subsection{Involved Processes and Influencing Factors for Irrigation of VGS}

The conceptual model is based on available literature on VGS and their water demand. The results of the literature research (as of 19 January 2021) provided 12 review papers. The thorough content search with the keywords showed that the keyword "water" covers "stormwater", "rainwater" and "water demand". From those 12 papers, six papers not containing the above-mentioned keyword relevant for VGS were removed. The remaining six papers were used to identify the relevant processes and influencing factors of VGS water demand and irrigation with rainwater run-off (Table 1). From those six review papers, 52 cited papers were identified for the keywords "water", "irrigation", "UHI" and "cooling" out of which 24 provided relevant information for the model development (Table 1).

Table 1. Overview of contributions related to the involved processes and influencing factors for irrigation of VGS with rainwater. Number of mentioned and relevant keywords in the review papers. Marked with a ${ }^{*}$ if the review paper was excluded.

\begin{tabular}{|c|c|c|c|c|c|c|c|c|}
\hline & \multicolumn{2}{|c|}{ Water } & \multicolumn{2}{|c|}{ Irrigation } & \multicolumn{2}{|c|}{ UHI } & \multicolumn{2}{|c|}{ Cooling } \\
\hline & Mentioned & Relevant & Mentioned & Relevant & Mentioned & Relevant & Mentioned & Relevant \\
\hline$[27]^{*}$ & 15 & 0 & 4 & 0 & 6 & 0 & 3 & 0 \\
\hline [26] & 20 & 1 & 28 & 4 & 3 & 1 & 34 & 4 \\
\hline$[28]^{*}$ & 24 & 0 & 2 & 0 & 0 & 0 & 0 & 0 \\
\hline$[29] *$ & 0 & 0 & 0 & 0 & 0 & 0 & 5 & 0 \\
\hline [30] & 107 & 13 & 9 & 3 & 5 & 0 & 10 & 3 \\
\hline [5] & 15 & 8 & 6 & 2 & 2 & 0 & 26 & 3 \\
\hline [31] & 27 & 5 & 28 & 4 & 0 & 0 & 4 & 1 \\
\hline$[32]^{*}$ & 16 & 0 & 0 & 0 & 0 & 0 & 26 & 0 \\
\hline [11] & 14 & 4 & 2 & 1 & 2 & 0 & 58 & 7 \\
\hline [33] & 38 & 7 & 4 & 0 & 2 & 0 & 39 & 0 \\
\hline$[34]^{*}$ & 140 & 0 & 0 & 0 & 0 & 0 & 10 & 0 \\
\hline [35] * & 15 & 0 & 0 & 0 & 0 & 0 & 12 & 0 \\
\hline
\end{tabular}

In concluding the literature research, the importance of adequate irrigation of VGS is generally acknowledged. However, little focus is placed on studying the actual water demand of VGS and the processes involved. Additionally, the supply of VGS with rainwater is often mentioned as a sustainable alternative to potable water, but the practical details of such systems (run-off areas, quality and technical design) are not well studied. Therefore, additional literature on the specifications and quality aspects of RWH systems [36,37] were added to the list of review papers.

\subsection{Conceptual Model}

The developed conceptual model comprises of five sub-modules (Figure 1). These sub-modules describe the influence of the atmosphere, the hydraulic characteristics, the 
run-off quality, the RWH system and the VGS on the irrigation of VGS with rainwater run-off.

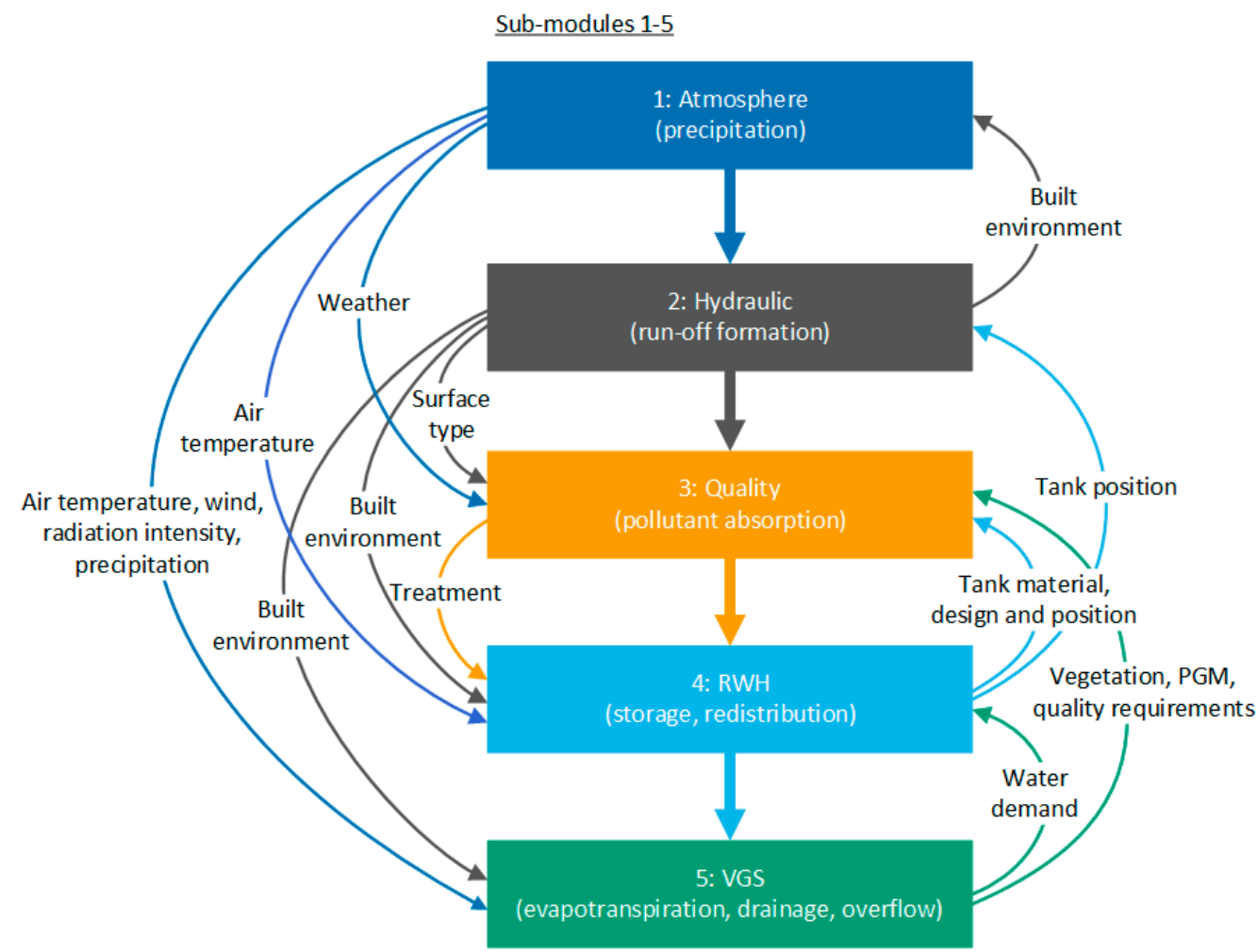

Figure 1. Sub-modules of the conceptual model describing the key factors for using rainwater run-off for irrigation of VGS. Each box represents a sub-module with the main module involved in hydrological processes in brackets. Straight arrows show water flow through the modules, while round arrows indicate influencing factors between the sub-modules.

Figure 1 illustrates the detailed interaction of processes and influencing factors between the five sub-modules. The general pathway of water can be described as follows. Precipitation is formed in the atmosphere (sub-module 1). Rainwater is falling on the surface area, forms run-off (sub-module 2) and washes off pollutants from the surfaces defining the treatment requirements (sub-module 3). The run-off is stored in a tank and further distributed (sub-module 4) to the VGS for irrigation (sub-module 5).

Next to the water pathway, influencing factors between the sub-modules are identified. In sub-module 1, the weather influences the pollution load in the quality sub-module. Furthermore, air temperature, radiation intensity, precipitation and wind are influencing the water demand of the VGS (sub-module 5) and the quality of stored run-off (sub-module 4). The built environment and surface type in sub-module 2 influence the quality of the run-off (sub-module 3) and the possible positions of the RWH and VGS (sub-module 4 and 5). Furthermore, the built environment influences atmospheric conditions such as radiation intensity or wind situation (sub-module 1). The chosen treatment of the collected run-off in sub-module 3 influences the total run-off yield in sub-module 4 . In sub-module 4 , the chosen storage tank material, design and position influences the quality of the collected run-off (sub-module 3). Furthermore, the tank position influences the possibility of runoff areas (sub-module 2) in the vicinity of the RWH system. Sub-module 5 influences the dimensioning of the storage tank (sub-module 4) and the required water quality for irrigation (sub-module 3).

\subsection{Description of Sub-Modules}

In the following chapters, the processes and influencing factors of each of the five sub-modules will be discussed in detail. An overview is presented in Table 2. 
Table 2. Processes and influencing factors identified in the five sub-modules that are relevant for the irrigation of VGS with rainwater run-off.

\begin{tabular}{|c|c|c|c|c|c|}
\hline & 1: Atmosphere & 2: Hydraulic & 3: Quality & 4: RWH & 5: VGS \\
\hline Processes & Precipitation & Run-off formation & $\begin{array}{l}\text { Pollutant } \\
\text { absorption }\end{array}$ & Run-off storage & Evapotranspiration \\
\hline \multirow{3}{*}{ Influencing factors } & & & & $\begin{array}{l}\text { Run-off } \\
\text { redistribution }\end{array}$ & $\begin{array}{l}\text { Drainage } \\
\text { Overflow; }\end{array}$ \\
\hline & $\begin{array}{l}\text { Radiation } \\
\text { intensity; }\end{array}$ & Catchment area; & Pollutant load; & Tank size; & Vegetation; \\
\hline & $\begin{array}{c}\text { Wind; } \\
\text { Air temperature; } \\
\text { Weather. }\end{array}$ & $\begin{array}{l}\text { Surface type; } \\
\text { Run-off coefficient; } \\
\text { Built environment. }\end{array}$ & Run-off treatment. & $\begin{array}{c}\text { Tank material; } \\
\text { Tank position; } \\
\text { Tank design; } \\
\text { Conveyance } \\
\text { system. }\end{array}$ & $\begin{array}{c}\text { PGM; } \\
\text { Plant containers; } \\
\text { Irrigation system; } \\
\text { Quality } \\
\text { requirements. }\end{array}$ \\
\hline
\end{tabular}

\subsubsection{Sub-Module 1: Atmosphere}

The atmospheric sub-module contains data on radiation intensity, air temperature, wind, precipitation and the weather condition, which, taken together, influences other sub-modules. In urban environments, plant growth in VGS is challenged by drastically changing atmospheric conditions regarding the incoming radiation, prevailing wind, air temperature conditions, precipitation patterns and generally the weather conditions (see Figure 1) [5,30].

Precipitation is one of the main influencing factors in the atmospheric sub-module. Spatial and temporal variations of precipitation dictate the available rainwater run-off from the chosen run-off surfaces and subsequently the storage calculation is presented in the RWH sub-module $[37,38]$. Precipitation data are suggested to be collected from daily datasets, as bigger time steps might neglect dry periods or extreme storm events [39]. Depending on the VGS design and exposition, precipitation can fall directly on the PGM as well, resulting in an increase in the soil moisture state in the PGM [40]. This change in the soil moisture state is considered in the antecedent precipitation index used in the VGS sub-module to calculate evapotranspiration from the VGS [41].

Wind conditions are influenced by the local weather, climate conditions and the urban environment. Buildings can create strong local winds around tall buildings, challenging plant growth in VGS $[5,39,42]$. Wind speed and direction influence PGM humidity, water vapor pressure deficits and the plant's transpiration rate, which influences the evapotranspiration rate and the water demand of VGS $[5,39,43-46]$. Furthermore, wind stress can harm plants mechanically. Therefore, wind conditions have to be considered when choosing plant species for VGS [39]. However, current literature lacks peer-reviewed studies on the effect of wind on the performance of VGS [5].

Radiation intensity is a driving force for evapotranspiration $[44,47,48]$ and subsequently an influencing factor for VGS water demand [49]. Radiation intensity is influenced by the location and the exposition of the VGS. In urban environments, radiation intensity can be reduced through casted shadows and increased through reflections by surrounding buildings $[5,39,50]$. The radiation intensity at a location might also vary between the lower and upper parts of the VGS, influencing the plant choice depending on their light requirements [39]. However, no studies have examined the influence of radiation intensity on the VGS performance in an urban environment in detail [5].

Increased air temperatures results in rising water vapor pressure deficits, which further enables an increase in evapotranspiration from VGS and thereby their water demand $[47,49,51]$. Increased air temperature can negatively influence plant health and root development [5,52]. Furthermore, air temperature influences the conditions in the RWH tank. High air temperatures can result in quality degradations in the tank due to bacterial 
growth. Low air temperatures can result in the freezing of the collected water with possible damages to the RWH infrastructure and problems of water provision during winter [53,54].

Furthermore, humidity influences the transpiration rate of plants. Low levels of relative humidity decreases transpiration as plants protect themselves from drying out. On the contrary, high levels of humidity increases transpiration [55].

The weather situation, with long drought periods or extreme storm events, influences the quality of the run-off collected. Drought periods foster the accumulation of pollutants on the surfaces, which will be washed off by the first flush of the next rain event [37].

\subsubsection{Sub-Module 2: Hydraulic}

In the hydraulic module, run-off formation is the prevailing process. Influencing factors include the run-off area, the run-off coefficient, the surface type and the built environment, which influences other sub-modules of the conceptual model (see Figure 1).

The run-off area is the chosen area where run-off is formed and from which run-off can be collected in the RWH system. The choice of the run-off surface area is dependent on the water demand for irrigation of the VGS $[38,56]$.

In many cases, only run-off collection from roofs is considered [36,37,57]. In order to increase yield, surface areas such as streets, pavements and courtyards should be included [20]. The main factor for the available run-off yield is the surface roughness and its inclination. The surface material, the use of the surface and the rainfall distribution influences the initial abstraction and the quality of the collected run-off. The initial abstraction is the rainfall stored on the run-off surface and is subsequently evaporated [56-58].

The run-off coefficient (RC) defines the share of rainwater that contributes to run-off and is used to calculate the run-off yield from the chosen run-off area. The RC is distinct for each surface type depending on the surface material and the slope. Typical values are 0.89 for an asphalt road, $>0.9$ for sloping smooth roofs and 0.62 for flat rough roofs $[56,57]$. The use of a constant RC is widespread in RWH calculation. However, recent studies have questioned this approach as results have shown a dependency of RC on rainfall intensity [58].

The run-off yield will change with surface choice, run-off area and precipitation height. The run-off yield is used for the dimensioning of the RWH tank and is calculated with the simplified rational method $[38,56]$ described as follows:

$$
Y_{t}=A \times h_{t} \times R C \times \eta
$$

where $Y_{t}$ is the run-off yield per day $\left(L^{3} \cdot T^{-1}\right)$, $A$ is the run-off area $\left(L^{2}\right), h_{t}$ is the precipita-

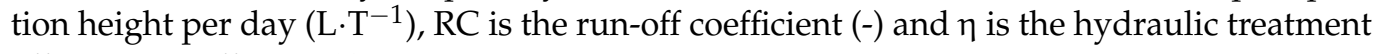
efficiency coefficient (-).

The hydraulic treatment efficiency coefficient describes the ratio of outgoing treated water to the incoming collected water. The coefficient is usually specified by the manufacturer. If no values are given, 0.9 can be used for the calculation [38].

\subsubsection{Sub-Module 3: Quality}

Pollutant absorption is the main process in the quality sub-module. The pollutant load and the treatment chosen for the prevailing run-off quality are influencing factors (see Figure 1).

In the urban environment, several different types of pollutants can be identified. Main sources are atmospheric pollution, animal waste, road traffic, pavement weathering and erosion, drain gates corrosion, public works, debris and others [36,57]. The quality of surface run-off should always be evaluated individually for the local conditions of the chosen areas. Potential pollutants from street and roof run-off are heavy metals, suspended solids, organic carbon, bacteria and chlorides [20]. Especially critical are emerging pollutants from urban run-offs. These include pesticides (used for gardening or on building materials), hydrocarbons such as polycyclic aromatic hydrocarbons (from oil spills, fuel, vehicle emissions, etc.), alkylphenols (from road and building material run-off), phthalates 
(majorly from traffic surfaces), per-fluorinated and polyfluorinated alkyl substances (from street and roof run-off) and polychlorinated biphenyls (from lubricants, hydraulic oils and house facades) [59].

The extent of the pollution is influenced by the characteristics and use of the surfaces and the weather conditions. Long periods of drought result in an increased accumulation of pollutants [37]. Generally, pollution load is dependent on the extent of use, so run-off from traffic surfaces is more polluted than from roof surfaces. Therefore, more polluted areas are not considered when speaking of RWH [20,36,37,57].

In order to remove the pollutants from run-off, treatment is necessary. The treatment of the collected run-off must be chosen based on the run-off quality and the required quality for irrigation, which are influenced by factors from the VGS and the RWH system. In the VGS, plant and PGM choice can allow the utilization of different pollutant loads in the irrigation water [60]. Still, a higher effort for planning and design of VGS would be required to integrate the run-off treatment in VGS, whereas a combination of pre-treatment and VGS is less complex [61]. Furthermore, water quality will deteriorate during storage, which is why long periods of storage should already be considered within the treatment requirements [37].

The treatment usually consists of a pre-treatment prior to storage but can also include an additional treatment after storage. Coarse filtration is used as a pre-treatment to remove large solids and to reduce the accumulation of organic matter in the storage tank [36]. First flush diversion is installed to divert the initial run-off volumes to the sewer to prevent the high pollution concentrations to be collected in the storage tank [36,37]. Additional treatment such as filtration or disinfection can be added to reduce risk for run-off reuse [36]. The choice of treatment influences the total run-off yield from the run-off areas (Equation (1)) with the hydraulic treatment efficiency coefficient $\eta$ specified by the manufacturer [38].

\subsubsection{Sub-Module 4: Rainwater Harvesting}

The main processes in the RWH sub-module are run-off storage and redistribution. The choice of the tank material, the sizing, the design and the position of the tank, as well as the conveyance system influences other sub-modules in the conceptual model (see Figure 1).

A RWH system consists of a storage tank and a conveyance system for the collection and further redistribution of the collected rainwater run-off [37]. Characteristics of the storage tank include the size, the material, the tank design and the position. The design of the storage tank influences the quality and quantity of the storage rainwater. Studies have shown quality differences between tanks with covers or screens and tightly seals tanks. Depending on its position, the inlet design also affects water quality since re-suspension in the tank can occur. Additionally, pollutants tend to settle at the bottom of the tank, which is why the position of the withdrawal tap should be carefully considered. The material of a tank can deteriorate the quality of the stored water, although the impact has shown to be less pronounced than that of the run-off surfaces [36].

The main influencing factors to respect within the RWH sub-module are the irrigation demands from the VGS sub-module as well as the precipitation pattern from the atmospheric sub-module. The task of the storage tank is to act as a buffer between those two modules. Due to the unpredictable and changing precipitation pattern, the time scale is important. Two approaches for determining the size of the storage tank are presented further.

In a basic approach, the storage sizing is only based on the mean daily water demand, calculated from the yearly irrigation water demand and the expected dry period in days. The storage volume is calculated as [38] follows:

$$
\mathrm{V}_{\mathrm{r}}=\mathrm{I}_{\mathrm{t}} \times \mathrm{d}_{\mathrm{d}}
$$

where $V_{r}$ is the rainwater volume in the storage tank $\left(L^{3}\right), I_{t}$ is the irrigation water demand per day $\left(\mathrm{L}^{3} \cdot \mathrm{T}^{-1}\right)$ and $\mathrm{d}_{\mathrm{d}}$ is the chosen dry period $(\mathrm{T})$. For Germany, a reference value of 21 days can be used. 
A second more detailed approach uses daily data and an algorithm to calculate the storage size to respect irregularities in irrigation demand and yield. An input-output simulation is used to calculate the overflow and required backup water for the system. The optimal storage size is then chosen by the planer, which balances the optimal tank size between backup and overflow [38]. The following describes the calculation:

$$
\begin{gathered}
\mathrm{S}_{\mathrm{r}, \mathrm{t}}=\min \left\{\mathrm{I}_{\mathrm{t}} ; \mathrm{V}_{\mathrm{r}, \mathrm{t}-1}\right\} \\
\mathrm{V}_{\mathrm{r}, \mathrm{t}}=\min \left\{\left(\mathrm{V}_{\mathrm{r}, \mathrm{t}-1}+\mathrm{Y}_{\mathrm{t}}-\mathrm{S}_{\mathrm{r}, \mathrm{t}}\right) ;\left(\mathrm{V}-\mathrm{S}_{\mathrm{r}, \mathrm{t}}\right)\right\}
\end{gathered}
$$

where $\mathrm{S}_{\mathrm{r}, \mathrm{t}}$ is the abstraction from the tank per day $\left(\mathrm{L}^{3} \cdot \mathrm{T}^{-1}\right)$, $\mathrm{I}_{\mathrm{t}}$ is the irrigation water demand per day $\left(\mathrm{L}^{3} \cdot \mathrm{T}^{-1}\right), \mathrm{V}_{\mathrm{r}, \mathrm{t}}$ is the rainwater volume in the storage tank per day $\left(\mathrm{L}^{3}\right), \mathrm{Y}_{\mathrm{t}}$ is the run-off yield per day $\left(\mathrm{L}^{3} \cdot \mathrm{T}^{-1}\right), \mathrm{V}$ is the useable volume of the tank $\left(\mathrm{L}^{3}\right)$ and $\mathrm{t}$ is the index for time.

In order to find the optimal tank size, the coverage rate is calculated for a range of storage volumes in the following:

$$
\mathrm{C}_{\mathrm{r}}(\mathrm{V})=\left(\sum_{\mathrm{t}} \mathrm{S}_{\mathrm{r}, \mathrm{t}}\right) /\left(\sum_{\mathrm{t}} \mathrm{I}_{\mathrm{t}}\right)
$$

where $C_{r}(V)$ is the coverage rate for a selected storage volume $(-), S_{r, t}$ is the abstraction from the tank $\left(\mathrm{L}^{3} \cdot \mathrm{T}^{-1}\right), \mathrm{I}_{\mathrm{t}}$ is the irrigation water demand per day $\left(\mathrm{L}^{3} \cdot \mathrm{T}^{-1}\right)$ and $\mathrm{t}$ is the index for time.

The coverage rate is plotted against the storage volume. The resulting curve helps to determine the optimal storage volume, which should ideally cover $100 \%$ of the water demand of the VGS.

The position of the RWH system is dependent on the built environment of the chosen run-off areas. Generally, storage tanks can be implemented above-ground or underground, resulting in different costs as well as operation and maintenance requirements [37]. For low density areas, a RWH system at building scale is recommended. The recommended storage types include a RWH tank distributed over the roof or an underground tank. For an area with high density, the position of the RWH system is suggested to either be at building scale or at block scale. A block tank is either located in the courtyard or in the cellar of one of the adjoining buildings [62].

Depending on the positioning of the tank, different parts of the conveyance system need to be included. For simple systems collecting only roof run-off, rain gutters will be sufficient [37], especially for ground based green facades. There, gravity driven irrigation is highly recommended. For bigger systems as well as systems collecting street run-off, pumps have to be included to convey the water to the VGS [20].

\subsubsection{Sub-Module 5: Vertical Greenery System}

The prevailing processes in the VGS sub-module are evapotranspiration (ET), drainage and overflow, all of which changes the soil water content in the VGS. The influencing factors in this module include the vegetation, the PGM, the design of the plant containers and the irrigation system [31].

Figure 2 shows the hydrological processes in the VGS sub-module in detail. Irrigation water from the RWH sub-module reaches the PGM surface and infiltrates into deeper layers. This process holds true when using either above-ground drip irrigation or subsurface irrigation pipes. When using soak irrigation, the irrigation water is added to an impoundment at the bottom of the VGS module. In this case, the water raises from the impoundment and is distributed by soil water fluxes [63]. When infiltrated from above, soil water fluxes are also predominant in further distributing the irrigation water. Depending on the design of the VGS, used access water will leave the VGS and either percolate into deeper soil layers or drain out of the system. Access water can also be fetched and transported back into the storage tank. When using fertigation, a combination of irrigation and fertilization [26] drainage water should not be recycled due to remaining nutrients. For systems with an impounded layer, water is stored at the bottom of the system within the PGM. From this 
storage, water can rise in the PGM by capillary forces and plant roots. Stored water in the upper layer and rainwater intercepted by the plant is prone to evaporation. In the cases where irrigation water cannot sufficiently infiltrate or the PGM is saturated, overflow from the VGS module occurs. The overflow is either drains back into the storage tank for reuse or is directed to the sewer system.

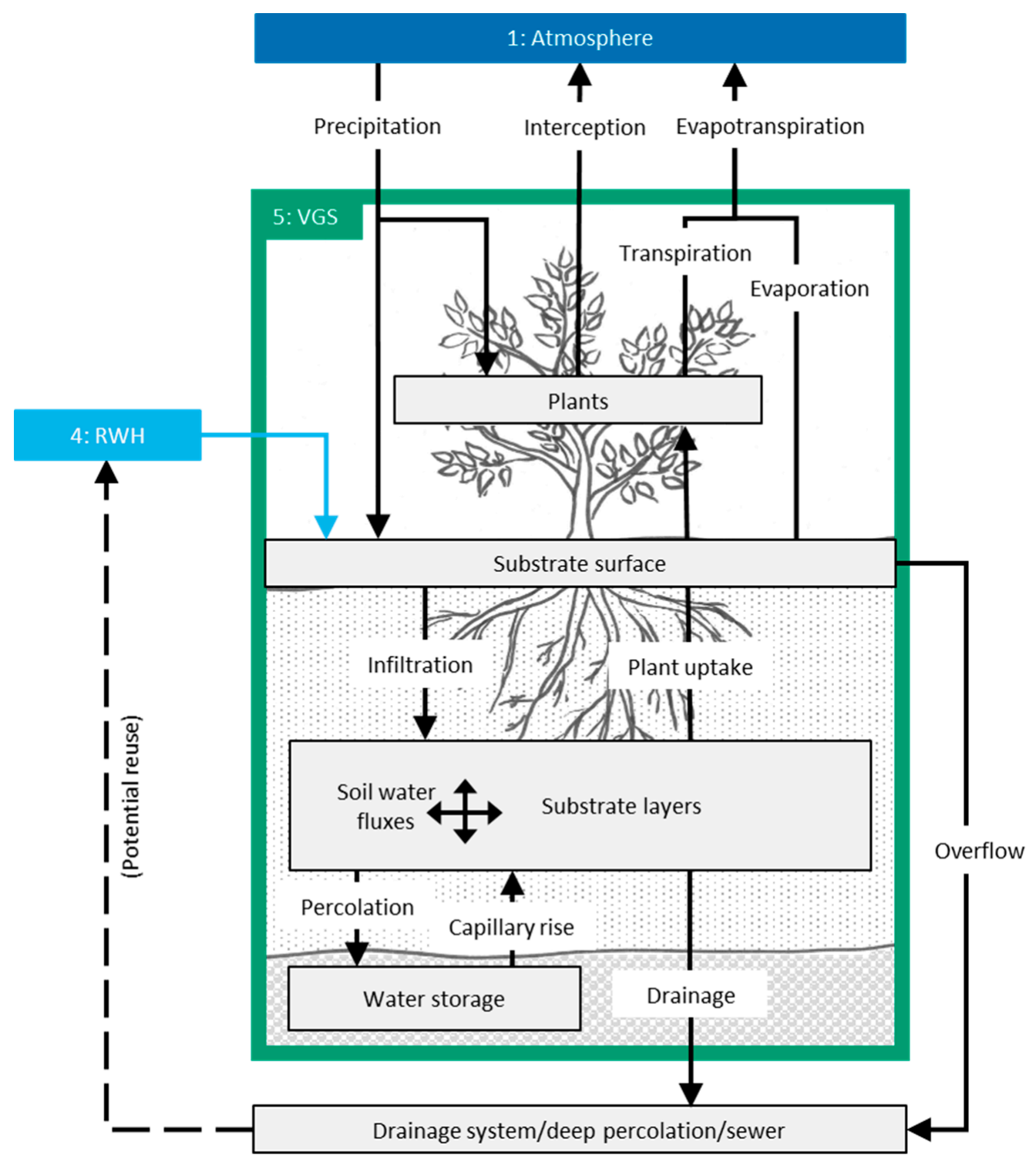

Figure 2. Detail of the hydrological processes involved in sub-module 5 VGS and the connections to sub-module 1 and 4 . Black arrows indicate water flow paths. Boxes represent features of VGS influencing the flow path of irrigation water.

The density of the plant canopy determines its ability to reflect, absorb and transmit radiation. This ability varies between species and their characteristics with respect to age, water content, leaf thickness, surface texture and orientation. All of these factors influence the vegetation's transpiration activity and thereby the water demand [5,8,11,26,30,44,55,64-67]. The choice of plant species for VGS must be based on the local environment by considering climate, built environment and the surrounding conditions of the VGS. Depending on the VGS type, climbing plants, shrubs, grasses, perennials and succulents are used [31]. Furthermore, the plant choice-between deciduous and evergreen-influences the ET potential throughout the year and consequently the water demand $[11,68]$. 
The properties of the PGM are important for plant health, root growth, water and pollutant retention capacity. Based on the specific soil hydraulic properties, e.g., residual and saturated water content, hydraulic conductivity, water capacity and air capacity as well the capillary rise, the plant water uptake is supported $[30,44,49,64]$. In order to ensure an efficient water uptake of the plants from the PGM, focus should be placed on providing an adequate ratio of pore space available for air and water in the PGM. This ration depends on the particle size distribution, the composition, the bulk density and the aging of the PGM. The particle size distribution defines the share of coarse and fine particles in the PGM and thereby the water retention curve. Coarse particles increase the number of pores available for air; however, they decrease the water retention capacity of the PGM. In contrast, PGM with a high share of fine particles enable a low availability of air in the PGM and decreases drainage [5,52]. The particle size distribution further influences capillary rise in the PGM. Capillary rise is important to provide an even distribution of irrigation water in the PGM $[49,69]$. The bulk density is the weight per volume of a PGM and represents an indicator of compaction. A combination of physical handling, particle size distribution, container design and time results in compaction in the PGM. The bulk density increases and results in decreased air pore space and consequently poor root and plant development. Lastly, the age of a PGM influences the physical characteristics over time, which is why PGM components with a high stability over time have to be chosen [5,52]. For systems using alternative PGM (geotextiles, etc.), the main processes and the equations of the irrigation water demand calculation do not change. However, specific parameters of the PGM need to be individually determined.

Theoretically, the plants can take up water when the water content is between FC and the permanent wilting point (PWP). Practically, the plant water uptake is already reduced before the water content at the PWP is reached. This threshold soil water volume is defined as the readily available water [70] and the water volume in a VGS module at this threshold is calculated as follows:

$$
\mathrm{V}_{\mathrm{RAW}}=p \times\left(\theta_{\mathrm{FC}}-\theta_{\mathrm{PWP}}\right) \times \mathrm{V}_{\mathrm{s}}
$$

where $V_{\text {RAW }}$ is the readily available water volume $\left(\mathrm{L}^{3}\right), p$ is the average fraction which can be depleted before plant moisture stress (-) (ranges from 0.3 to 0.7 , but can be set to a value of 0.5 for many crops [70]), $\theta_{\mathrm{FC}}$ is the water content at field capacity (-), $\theta_{\mathrm{PWP}}$ is the water content at the permanent wilting point (-) and $V_{S}$ is the PGM volume $\left(\mathrm{L}^{3}\right)$.

The water volume in the PGM can be calculated as follows:

$$
\mathrm{V}_{\mathrm{m}, \mathrm{t}}=\mathrm{V}_{\mathrm{m}, \mathrm{t}-1}+\Delta \mathrm{t} \times\left(\mathrm{Q}_{\text {overflow } \mathrm{m}-1, \mathrm{t}}+\mathrm{Q}_{\mathrm{d} \mathrm{m}-1, \mathrm{t}}-\mathrm{ET}_{\mathrm{m}, \mathrm{t}}-\mathrm{Q}_{\mathrm{d} \mathrm{m}, \mathrm{t}}-\mathrm{Q}_{\text {overflow } \mathrm{m}, \mathrm{t}}\right)
$$

where $\mathrm{m}$ is the index for the module, $\mathrm{t}$ is the index for time, $\mathrm{V}_{\mathrm{m}, \mathrm{t}}$ is the water volume in the PGM $\left(\mathrm{L}^{3} \cdot \mathrm{T}^{-1}\right), \mathrm{Q}_{\text {overflow } \mathrm{m}, \mathrm{t}}$ is the overflow volume per day $\left(\mathrm{L}^{3} \cdot \mathrm{T}^{-1}\right), \mathrm{ET}_{\mathrm{m}, \mathrm{t}}$ is the evapotranspiration per day $\left(\mathrm{L}^{3} \cdot \mathrm{T}^{-1}\right)$ and $\mathrm{Q}_{\mathrm{d}, \mathrm{t}}$ is the drainage volume $\left(\mathrm{L}^{3} \cdot \mathrm{T}^{-1}\right)$.

Through ET from the PGM and the plants, water is leaving the VGS module, resulting in a reduction in the soil water content. In this paper, ET is calculated as an example based on the Priestley-Taylor equation and the antecedent precipitation index (API), but other approaches can also be used [41]. The API uses the daily irrigation depths for the last 28 days to take into account their influence on the current state of the soil moisture in the PGM [71]. Empirical values of the constants in the following equations are based on the cited literature. AET is calculated with the following formula [71,72]:

$$
\mathrm{AET}=0.408 \alpha\left[(\Delta /(\Delta+\gamma)) \times\left(\mathrm{R}_{\mathrm{n}}-\mathrm{G}\right)\right]
$$

where AET is the actual evapotranspiration flux $(\mathrm{L} \cdot \mathrm{T}), \alpha$ is the reduction coefficient $(-), \Delta$ is the slope of the saturation vapor pressure-temperature curve $\left(\mathrm{M} \cdot \mathrm{L}^{-1} \cdot \mathrm{T}^{-2} \cdot \theta^{-1}\right), \gamma$ is the psychrometric constant $\left(\mathrm{M} \cdot \mathrm{L}^{-1} \cdot \mathrm{T}^{-2} \cdot \theta^{-1}\right), \mathrm{R}_{\mathrm{n}}$ is the net radiation $\left(\mathrm{M} \cdot \mathrm{T}^{-3}\right)$ and $\mathrm{G}$ is the soil heat-flux density at the soil surface $\left(\mathrm{M} \cdot \mathrm{T}^{-3}\right)$. 
The slope of the saturation vapor pressure-temperature is calculated as follows:

$$
\Delta=4098 \times\left[0.6108 \exp \left(17.27 \times \mathrm{T}_{\text {mean }} /\left(\mathrm{T}_{\text {mean }}+237.3\right)\right)\right] /\left(237.3+\mathrm{T}_{\text {mean }}\right)^{2}
$$

where $\Delta$ is the slope of the saturation vapor pressure-temperature curve $\left(\mathrm{M} \cdot \mathrm{L}^{-1} \cdot \mathrm{T}^{-2} \cdot \theta^{-1}\right)$ and $T_{\text {mean }}$ is the average air temperature between maximum and minimum values $(\theta)$.

The coefficient $\alpha$ is calculated as follows:

$$
\begin{aligned}
\text { if } \mathrm{API} \leq 20 \mathrm{~mm}: \alpha= & 0.123(\mathrm{API})-0.0029(\mathrm{API})^{2}-0.0000056(\mathrm{API})^{3} \\
& \text { if API }>20 \mathrm{~mm}: \alpha=1.26
\end{aligned}
$$

where API is the antecedent precipitation index (L) and $\alpha$ is the reduction coefficient (-).

The API is calculated as [71] follows:

$$
\mathrm{API}_{\mathrm{t}}=\sum_{\mathrm{d}=1 \rightarrow 28}\left(\mathrm{~K}^{\mathrm{d}-1} \times \mathrm{I}_{\mathrm{t}-\mathrm{d}}\right)
$$

where API is the antecedent precipitation index $(\mathrm{L}), \mathrm{t}$ is the index for time $(\mathrm{T}), \mathrm{d}$ is the index for the values 1 to $28(\mathrm{~T}), \mathrm{K}$ is the dimensionless recession constant set to $0.9(-)$ and $\mathrm{I}_{\mathrm{t}}$ is the irrigation water demand per day $\left(\mathrm{L}^{3} \cdot \mathrm{T}^{-1}\right)$.

The total ET is calculated as follows:

$$
\mathrm{ET}=\mathrm{AET} \times \mathrm{A}_{\mathrm{g}}
$$

where AET is the actual evapotranspiration flux $(\mathrm{L} \cdot \mathrm{T})$ and $\mathrm{A}_{\mathrm{g}}$ is the greened area $\left(\mathrm{L}^{2}\right)$.

Furthermore, overflow from VGS occurs if the water volume in the module exceeds the maximum volume containable in the PGM. Overflow is calculated as [73] follows:

$$
\begin{gathered}
\text { if } V_{m, t} \leq V_{\max }: Q_{\text {overflow } m, t}=0 \\
\text { if } V_{m, t}>V_{\max }: Q_{\text {overflow } m, t}=V_{m, t}-V_{\max }
\end{gathered}
$$

where $m$ is the index for the module, $t$ is the index for time, $V_{m, t}$ is the water volume in the PGM $\left(\mathrm{L}^{3} \cdot \mathrm{T}^{-1}\right), \mathrm{Q}_{\text {overflow } m, t}$ is the overflow volume per day $\left(\mathrm{L}^{3} \cdot \mathrm{T}^{-1}\right)$ and $\mathrm{V}_{\max }$ is the maximum water volume that can be retained in the VGS $\left(\mathrm{L}^{3}\right)$.

The design of the plant containers include the position and dimensions of an impoundment for water storage and of the drainage opening, both of which further determines the amount of drainage from the VGS [74].

Drainage from the VGS module is induced by gravity and reduces the water content in the PGM. The excess drainage water can be reused for irrigation if the system design (recirculation system intended) and the quality of the drainage water (deterioration of water quality due to fertilization residues) allows for it [31,37].

In this paper, drainage is calculated using the drainage rate and the area of the drainage opening. Drainage only begins when the water volume in the module exceeds the water volume at field capacity (FC) and the soil cannot hold additional water. Drainage volume is affected by ET and PGM moisture levels [64]. Drainage is calculated as follows [74]:

$$
\begin{gathered}
\text { if } V_{m, t} \leq V_{F C}: Q_{d m, t}=0 \\
\text { if } V_{m, t}>V_{F C}: Q_{d m, t}=A_{d} \times d_{e}=A_{d} \times\left(\left(\theta_{t}-\theta_{F C}\right) \times\left(1-e^{\left(-\Delta t / t_{t}\right)}\right) \times n / \Delta t\right)
\end{gathered}
$$

where $m$ is the index for the module, $t$ is the index for time, $V_{m, t}$ is the water volume in the $\operatorname{PGM}\left(\mathrm{L}^{3} \cdot \mathrm{T}^{-1}\right), \mathrm{V}_{\mathrm{FC}}$ is the water volume at field capacity $\left(\mathrm{L}^{3}\right), \mathrm{Q}_{\mathrm{d}, \mathrm{t}}$ is the drainage volume $\left(\mathrm{L}^{3} \cdot \mathrm{T}^{-1}\right), \mathrm{d}_{\mathrm{e}}$ is the drainage rate $\left(\mathrm{L} \cdot \mathrm{T}^{-1}\right), \mathrm{A}_{\mathrm{d}}$ is the area of the drainage opening $\left(\mathrm{L}^{2}\right), \theta_{t}$ is the water content $(-), \theta_{\mathrm{FC}}$ is the water content at field capacity $(-), \mathrm{t}_{\mathrm{t}}$ is the travel time of water through the module/layer $(\mathrm{T}), \mathrm{n}$ is the thickness of the module/layer $(\mathrm{L})$ and $\mathrm{e}$ is Euler's number and equals to approximately 2.718 .

The water volume $\mathrm{V}_{\mathrm{FC}}$ can be calculated with the following equation:

$$
\mathrm{V}_{\mathrm{FC}}=\theta_{\mathrm{FC}} \times \mathrm{V}_{\mathrm{s}}
$$


where $\theta_{\mathrm{FC}}$ is the water content at field capacity (-) and $\mathrm{V}_{\mathrm{s}}$ is the PGM volume $\left(\mathrm{L}^{3}\right)$.

The travel time $t_{t}$ can be written as the following:

$$
\mathrm{t}_{\mathrm{t}}=\left(\theta_{\mathrm{t}}-\theta_{\mathrm{FC}}\right) / \mathrm{k}_{\text {unsat }} \times \mathrm{n}
$$

where $\theta_{\mathrm{t}}$ is the water content $(-), \theta_{\mathrm{FC}}$ is the water content at field capacity $(-), \mathrm{k}_{\text {unsat }}$ is the unsaturated hydraulic conductivity in the module $\left(\mathrm{L} \cdot \mathrm{T}^{-1}\right)$ and $\mathrm{n}$ is the thickness of the module/layer (L). The unsaturated hydraulic conductivity can be calculated according to the formula used by Herrera et al. [74].

Optimal irrigation should ensure that the water volume remains in the PGM between $\mathrm{V}_{\mathrm{RAW}}$ and $\mathrm{V}_{\mathrm{FC}}$ (Equation (15)). The amount of optimal irrigation can be calculated as the following:

$$
\begin{gathered}
\text { if } V_{m, t}>V_{R A W}: I_{t}=0 \\
\text { if } V_{m, t} \leq V_{R A W}: I t=\sum_{m=1 \rightarrow M}\left(V_{F C}-V_{m, t}\right) / \Delta t
\end{gathered}
$$

where $m$ is the index for the module, $t$ is the index for time, $V_{m, t}$ is the water volume in the $\operatorname{PGM}\left(\mathrm{L}^{3} \cdot \mathrm{T}^{-1}\right), \mathrm{V}_{\mathrm{RAW}}$ is the readily available water volume $\left(\mathrm{L}^{3}\right), \mathrm{I}_{t}$ is the irrigation water demand per day $\left(\mathrm{L}^{3} \cdot \mathrm{T}^{-1}\right), \mathrm{V}_{\mathrm{FC}}$ is the water volume at field capacity $\left(\mathrm{L}^{3}\right)$ and $\mathrm{M}$ is the total number of VGS modules (-).

With the above-mentioned formulas, the irrigation water demand of VGS can be calculated. This irrigation water demand influences the choice of storage size in the RWH sub-module. The quality of the irrigation water should conform to non-potable quality guidelines [36,37]. The quality requirements are dependent on the plant and PGM choice in the VGS.

\subsection{Boundary Conditions}

The boundary conditions describe the differences in the water demand calculation for the two main VGS types: living walls and green facades. Due to the system design, the input and output parameters for Equation (7) vary for the two types.

The water volume in the PGM of living walls $\mathrm{V}_{\mathrm{LWS}} \mathrm{m}, \mathrm{t}$ is increased by overflow and drainage from previous modules and decreased by ET, drainage and overflow as described as follows:

$$
\mathrm{V}_{\mathrm{LWS}, \mathrm{t}}=\mathrm{V}_{\mathrm{m}, \mathrm{t}-1}+\Delta \mathrm{t} \times\left(\mathrm{Q}_{\text {overflow } \mathrm{m}-1, \mathrm{t}}+\mathrm{Q}_{\mathrm{dm}-1, \mathrm{t}}-\mathrm{ET}_{\mathrm{m}, \mathrm{t}}-\mathrm{Q}_{\mathrm{d}, \mathrm{t}}-\mathrm{Q}_{\text {overflow } \mathrm{m}, \mathrm{t}}\right.
$$

where $m$ is the index for the module, $t$ is the index for time, $V_{L W S} m, t$ is the water volume in the PGM of living walls $\left(\mathrm{L}^{3} \cdot \mathrm{T}^{-1}\right), \mathrm{Q}_{\text {overflow }} \mathrm{m}, \mathrm{t}$ is the overflow volume per day $\left(\mathrm{L}^{3} \cdot \mathrm{T}^{-1}\right)$, $\mathrm{Q}_{\mathrm{d}, \mathrm{t}}$ is the drainage volume $\left(\mathrm{L}^{3} \cdot \mathrm{T}^{-1}\right)$ and $\mathrm{ET}_{\mathrm{m}, \mathrm{t}}$ is the evapotranspiration per day $\left(\mathrm{L}^{3} \cdot \mathrm{T}^{-1}\right)$.

In contrast, green facades do not receive water from drainage or overflow from previous modules. Therefore, the water volume in the PGM of green facades $V_{G F} m$, is decreased by ET, drainage and overflow as described as follows:

$$
\mathrm{V}_{\mathrm{GF}, \mathrm{t}}=\mathrm{V}_{\mathrm{m}, \mathrm{t}-1}-\Delta \mathrm{t} \times\left(\mathrm{ET}_{\mathrm{m}, \mathrm{t}}+\mathrm{Q}_{\mathrm{d}, \mathrm{t}}+\mathrm{Q}_{\text {overflow } \mathrm{m}, \mathrm{t}}\right)
$$

where $m$ is the index for the module, $t$ is the index for time, $V_{G F} m$ is the water volume in the PGM of green facades $\left(\mathrm{L}^{3} \cdot \mathrm{T}^{-1}\right), \mathrm{ET}_{\mathrm{m}, \mathrm{t}}$ is the evapotranspiration per day $\left(\mathrm{L}^{3} \cdot \mathrm{T}^{-1}\right), \mathrm{Q}_{\mathrm{d}, \mathrm{t}}$ is the drainage volume $\left(\mathrm{L}^{3} \cdot \mathrm{T}^{-1}\right)$ and $\mathrm{Q}_{\text {overflow } m, t}$ is the overflow volume per day $\left(\mathrm{L}^{3} \cdot \mathrm{T}^{-1}\right)$.

\section{Discussion}

A specific literature review on the use of rainwater for the irrigation of VGS was carried out. The results show that VGS are often promoted as an NbS for the provision of cooling and energy saving. However, the water and energy demand provided to these processes and the water resource are often neglected $[5,67]$. Therefore, this paper focused on the sustainable irrigation with rainwater. The results of the literature review are combined in a conceptual model, showing the main processes and influencing factors. Regarding the atmosphere and the VGS, processes influencing the water demand and water availability 
are known in literature $[5,11,26,30,35]$. However, knowledge gaps are identified regarding details of combining RWH and VGS irrigation.

The high potential of rainwater use is often mentioned in VGS literature. However, details on the practical implementation are often missing $[26,33,75,76]$ and are only mentioned in a few studies $[24,75,76]$. In many cases, studies from the green roof community are used to support the feasibility of rainwater for VGS irrigation $[5,30,33,77]$. In the conceptual model presented in this paper, sub-module 5 represents the VGS and the processes and influencing factors involved in the formation of the VGS water demand. Here, the design of the plant container, the chosen vegetation, PGM and irrigation are influential. Compared to green roofs, their implementation differs for VGS. Therefore, the use of rainwater for irrigating VGS should not be based on to the irrigation of green roofs with rainwater.

Apart from an alternative irrigation resources, rainwater and VGS are often mentioned in the context of urban stormwater management. However, literature research has shown that the benefit of retaining stormwater in VGS is often based on the ability of green roofs to contribute to stormwater management and the assumption that the two systems behave in the same manner $[5,30,78]$. Few studies have investigated the potential of VGS to contribute to stormwater management [54,79]. Kew et al. [54] state in their publication that the contribution of VGS in stormwater management is based on the ability of the RWH system to temporarily store collected water. The role of VGS is to dispose the water. The conceptual model shows this interrelation between components in sub-module 4 and 5. Collected rainwater is stored in the RWH sub-module and diverted to the VGS for irrigation.

In sub-module 2, the processes and influencing factors of RWH are described. In order to achieve the highest possible run-off amount for later irrigation, rainwater run-off from roof and street areas are included. In the literature, run-off from street areas is often excluded due to an expected higher pollution [36,37]. However, Nolde et al. [20] have shown that both run-off areas can be successfully used for RWH. In the conceptual model, the pollution level is reflected in sub-module 3 (quality). There, the required treatment has to be chosen depending on the pollution level of the run-off. For future research, the authors suggest looking into the practical implementation of run-off from roof and street surfaces for irrigating VGS.

In order to ensure healthy plant growth and well-functioning of VGS, an understanding of the detailed processes in the VGS is important. However, based on the literature a lack research and knowledge regarding some of these processes and their interaction became evident. Therefore, the conceptual model provides an understanding of the involved processes and influencing factors in sub-module 5 . The water demand of VGS is calculated exemplarily based on the optimal soil water content for plant growth. The relevant processes changing the soil water are identified to be evapotranspiration, drainage and overflow. However, studies have shown that precipitation can be intercepted on VGS leaves and PGM surfaces $[40,80]$. The results of the literature research suggest that the influence of interception on the VGS water demand is not well investigated. More research is needed to further develop the conceptual model and to include the process of interception. Furthermore, the validation of the water demand calculation requires investigation in future research projects.

As described in sub-module 5, the irrigation amount should be planned to produce no drainage to minimal drainage from the system. Still, a reuse of drainage water from VGS is described in the literature [31]. At the same time, some VGS are irrigated with nutrient enriched water, also called fertigation [8,26,31,49]. When planning a reuse of drainage water, the conceptual model shows that sub-module 4 (RWH) and 5 (VGS) must be considered. If nutrient enriched drainage water is redirected to the storage tank, water quality issues might arise [37]. 


\section{Conclusions}

The following conclusions can be drawn:

- The irrigation of VGS with rainwater can be depicted by five sub-modules: the atmospheric, hydraulic, quality, RWH and VGS sub-module.

- The conceptual model shows the main processes and influencing factors of these five sub-modules, which are relevant for a holistic understand of VGS irrigation with rainwater.

- The optimal irrigation amount of VGS is dependent on the soil water content. If the soil water content drops below the readily available water, additional water input via irrigation is necessary.

- The soil water content is changed by the inflows and outflows to the VGS, which are evapotranspiration, overflow from the system and drainage. These processes are altered by influencing factors from the other sub-modules.

- Different designs of VGS result in changes of the inflows and outflows. For the calculation of the irrigation demand, the boundary conditions for each type must be considered.

- $\quad$ The conceptual model helps to identify the available RWH potential and at what point another resource for irrigation will be needed to cover the actual VGS demand.

The conceptual model presented in this paper supports the development of solutions for sustainable irrigation practices. The use of rainwater for irrigation closes the local water cycle and reduces the depletion of potable water resources. This resource-oriented irrigation contributes towards circularity in urban water management. In order to achieve further advancements in this field, an understanding of the involved processes and of the interrelation between the system components is essential. It is therefore recommended that future projects consider the conceptual model presented here and how VGS interacts with RWH and their urban surrounding.

Author Contributions: Conceptualization, F.P. and I.Z.; methodology, F.P. and B.P.; data curation, F.P.; writing — original draft preparation, F.P. and B.P.; writing—review and editing, I.Z. and G.L.; supervision, U.P.; funding acquisition, U.P. and G.L. All authors have read and agreed to the published version of the manuscript.

Funding: This research was funded by the SUGI-FWE Nexus Joint Programming Initiative Urban Europe, grant number 16485002 of the project “Urban Vertical Greening 2.0: Vertical greening for livable cities-co-create innovation for the breakthrough of an old concept" for a duration of 3 years from April 2017 to October 2021. The authors are grateful for the support. The APC was paid by the COST Action CA17133 Circular City, supported by COST (European Cooperation in Science and Technology). www.cost.eu.

Institutional Review Board Statement: Not applicable.

Informed Consent Statement: Not applicable.

Data Availability Statement: Not applicable.

Acknowledgments: Bernhard Pucher is part of the Doctoral School HR21 (BOKU) and their support is appreciated.

Conflicts of Interest: The authors declare no conflict of interest. 


\section{Abbreviations}

A run-off area (L2)

$\alpha \quad$ reduction coefficient (-)

$\mathrm{A}_{\mathrm{d}} \quad$ area of the drainage opening (L2)

AET actual evapotranspiration flux (L.T)

$\mathrm{A}_{\mathrm{g}} \quad$ greened area (L2)

API antecedent precipitation index (L)

$\mathrm{C}_{\mathrm{r}}(\mathrm{V})$ coverage rate for a selected storage volume (-) slope of the saturation vapour pressure-temperature

$\Delta$ curve $\left(\mathrm{M} \cdot \mathrm{L}^{-1} \cdot \mathrm{T}^{-2} \cdot \theta^{-1}\right)$

$\mathrm{d} \quad$ index for the values 1 to $28(\mathrm{~T})$

$\mathrm{d}_{\mathrm{d}} \quad$ dry period $(\mathrm{T})$

$\mathrm{d}_{\mathrm{e}} \quad$ drainage rate $\left(\mathrm{L} \cdot \mathrm{T}^{-1}\right)$

e Euler's number

ET evapotranspiration

$\mathrm{ET}_{\mathrm{m}, \mathrm{t}}$ evapotranspiration per day $\left(\mathrm{L} 3 \cdot \mathrm{T}^{-1}\right)$

$\mathrm{G} \quad$ soil heat-flux density at the soil surface $\left(\mathrm{M} \cdot \mathrm{T}^{-3}\right)$

$h_{t} \quad$ precipitation height per day $\left(\mathrm{L} \cdot \mathrm{T}^{-1}\right)$

$\mathrm{I}_{\mathrm{t}} \quad$ irrigation water demand per day $\left(\mathrm{L} 3 \cdot \mathrm{T}^{-1}\right)$

K dimensionless recession constant (-)

$\mathrm{k}_{\text {unsat }}$ unsaturated hydraulic conductivity in the

module $\left(\mathrm{L} \cdot \mathrm{T}^{-1}\right)$

$\mathrm{m} \quad$ index for the module

M total number of VGS modules (-)

$\eta \quad$ hydraulic treatment efficiency coefficient (-)

$\mathrm{n} \quad$ thickness of the module/layer (L)

$\mathrm{NbS}$ nature-based solution

average fraction which can be depleted before plant

p moisture stress (-)

PGM plant growing media

PWP permanent wilting point

\begin{tabular}{|c|c|}
\hline $\mathrm{Q}_{\mathrm{d} m, \mathrm{t}}$ & drainage volume $\left(\mathrm{L}^{3} \cdot \mathrm{T}^{-1}\right)$ \\
\hline$\theta_{\mathrm{FC}}$ & water content at field capacity (-) \\
\hline$Q_{\text {overflow } m, t}$ & overflow volume per day $\left(\mathrm{L}^{3} \cdot \mathrm{T}^{-1}\right)$ \\
\hline$Q_{\mathrm{d} m, \mathrm{t}}$ & drainage volume $\left(\mathrm{L}^{3} \cdot \mathrm{T}^{-1}\right)$ \\
\hline$\theta_{\mathrm{PWP}}$ & water content at the permanent wilting point (-) \\
\hline$\theta_{\mathrm{t}}$ & the water content (-) \\
\hline $\mathrm{RC}$ & run-off coefficient (-) \\
\hline $\mathrm{R}_{\mathrm{n}}$ & net radiation $\left(\mathrm{M} \cdot \mathrm{T}^{-3}\right)$ \\
\hline RWH & rainwater harvesting \\
\hline$S_{\mathrm{r}, \mathrm{t}}$ & abstraction from the tank per day $\left(\mathrm{L}^{3} \cdot \mathrm{T}^{-1}\right)$ \\
\hline $\mathrm{t}$ & index for time $(\mathrm{T})$ \\
\hline $\mathrm{T}_{\text {mean }}$ & $\begin{array}{l}\text { average air temperature between maximum and } \\
\text { minimum values }(\theta)\end{array}$ \\
\hline$t_{t}$ & travel time of water through the module/layer $(\mathrm{T})$ \\
\hline UHI & urban heat island \\
\hline $\mathrm{V}$ & useable volume of the tank $\left(\mathrm{L}^{3}\right)$ \\
\hline $\mathrm{V}_{\mathrm{FC}}$ & water volume at field capacity $\left(\mathrm{L}^{3}\right)$ \\
\hline $\mathrm{V}_{\mathrm{GF} \mathrm{m,t}}$ & water volume in the PGM of green facades $\left(\mathrm{L}^{3} \cdot \mathrm{T}^{-1}\right)$ \\
\hline VGS & vertical greenery system \\
\hline $\mathrm{V}_{\text {LWS } \mathrm{m}, \mathrm{t}}$ & water volume in the PGM of living walls $\left(\mathrm{L}^{3} \cdot \mathrm{T}^{-1}\right)$ \\
\hline $\mathrm{V}_{\mathrm{m}, \mathrm{t}}$ & water volume in the PGM $\left(\mathrm{L}^{3} \cdot \mathrm{T}^{-1}\right)$ \\
\hline $\mathrm{V}_{\max }$ & $\begin{array}{l}\text { maximum water volume that can be retained in the } \\
\text { VGS }\left(\mathrm{L}^{3}\right)\end{array}$ \\
\hline $\mathrm{V}_{\mathrm{r}, \mathrm{t}}$ & rainwater volume in the storage tank per day $\left(\mathrm{L}^{3}\right)$ \\
\hline $\mathrm{V}_{\mathrm{RAW}}$ & readily available water volume $\left(\mathrm{L}^{3}\right)$ \\
\hline $\mathrm{V}_{\mathrm{S}}$ & PGM volume $\left(\mathrm{L}^{3}\right)$ \\
\hline$Y_{t}$ & run-off yield per day $\left(\mathrm{L}^{3} \cdot \mathrm{T}^{-1}\right)$ \\
\hline$y$ & psychrometric constant $\left(\mathrm{M} \cdot \mathrm{L}^{-1} \cdot \mathrm{T}^{-2} \cdot \theta^{-1}\right)$ \\
\hline
\end{tabular}

\section{References}

1. Madsen, H.; Lawrence, D.; Lang, M.; Martinkova, M.; Kjeldsen, T. Review of trend analysis and climate change projections of extreme precipitation and floods in Europe. J. Hydrol. 2014, 519, 3634-3650. [CrossRef]

2. Ellena, M.; Breil, M.; Soriani, S. The heat-health nexus in the urban context: A systematic literature review exploring the socio-economic vulnerabilities and built environment characteristics. Urban Clim. 2020, 34, 100676. [CrossRef]

3. Gabriel, K.M.; Endlicher, W.R. Urban and rural mortality rates during heat waves in Berlin and Brandenburg, Germany. Environ. Pollut. 2011, 159, 2044-2050. [CrossRef]

4. Köhler, M. Green facades—a view back and some visions. Urban Ecosyst. 2008, 11, 423-436. [CrossRef]

5. Hunter, A.M.; Williams, N.; Rayner, J.P.; Aye, L.; Hes, D.; Livesley, S. Quantifying the thermal performance of green façades: A critical review. Ecol. Eng. 2014, 63, 102-113. [CrossRef]

6. Alexandri, E.; Jones, P. Temperature decreases in an urban canyon due to green walls and green roofs in diverse climates. Build. Environ. 2008, 43, 480-493. [CrossRef]

7. Hoelscher, M.-T.; Nehls, T.; Jänicke, B.; Wessolek, G. Quantifying cooling effects of facade greening: Shading, transpiration and insulation. Energy Build. 2016, 114, 283-290. [CrossRef]

8. Cameron, R.W.; Taylor, J.E.; Emmett, M.R. What's ' $\mathrm{Cool}^{\prime}$ in the world of green façades? How plant choice influences the cooling properties of green walls. Build. Environ. 2014, 73, 198-207. [CrossRef]

9. Price, A.; Jones, E.C.; Jefferson, F. Vertical Greenery Systems as a Strategy in Urban Heat Island Mitigation. Water Air Soil Pollut. 2015, 226, 1-11. [CrossRef]

10. Šuklje, T.; Medved, S.; Arkar, C. On detailed thermal response modeling of vertical greenery systems as cooling measure for buildings and cities in summer conditions. Energy 2016, 115, 1055-1068. [CrossRef]

11. Pérez, G.; Coma, J.; Martorell, I.; Cabeza, L.F. Vertical Greenery Systems (VGS) for energy saving in buildings: A review. Renew. Sustain. Energy Rev. 2014, 39, 139-165. [CrossRef] 
12. Santamouris, M.; Ding, L.; Fiorito, F.; Oldfield, P.; Osmond, P.; Paolini, R.; Prasad, D.; Synnefa, A. Passive and active cooling for the outdoor built environment-Analysis and assessment of the cooling potential of mitigation technologies using performance data from 220 large scale projects. Sol. Energy 2017, 154, 14-33. [CrossRef]

13. Langergraber, G.; Pucher, B.; Simperler, L.; Kisser, J.; Katsou, E.; Buehler, D.; Mateo, M.C.G.; Atanasova, N. Implementing nature-based solutions for creating a resourceful circular city. Blue-Green Syst. 2020, 2, 173-185. [CrossRef]

14. Nika, C.; Gusmaroli, L.; Ghafourian, M.; Atanasova, N.; Buttiglieri, G.; Katsou, E. Nature-based solutions as enablers of circularity in water systems: A review on assessment methodologies, tools and indicators. Water Res. 2020, 183, 115988. [CrossRef]

15. Fowdar, H.S.; Hatt, B.E.; Breen, P.; Cook, P.L.; Deletic, A. Designing living walls for greywater treatment. Water Res. 2017, 110, 218-232. [CrossRef] [PubMed]

16. Masi, F.; Bresciani, R.; Rizzo, A.; Edathoot, A.; Patwardhan, N.; Panse, D.; Langergraber, G. Green walls for greywater treatment and recycling in dense urban areas: A case-study in Pune. J. Water, Sanit. Hyg. Dev. 2016, 6, 342-347. [CrossRef]

17. Pradhan, S.; Al-Ghamdi, S.G.; Mackey, H.R. Greywater recycling in buildings using living walls and green roofs: A review of the applicability and challenges. Sci. Total Environ. 2019, 652, 330-344. [CrossRef] [PubMed]

18. Boano, F.; Caruso, A.; Costamagna, E.; Fiore, S.; Demichelis, F.; Galvão, A.; Pisoeiro, J.; Rizzo, A.; Masi, F. Assessment of the Treatment Performance of an Open-Air Green Wall Fed with Graywater under Winter Conditions. ACS ESET Water 2021, 1, 595-602. [CrossRef]

19. Shi, Y.; Yang, G.; Du, Y.; Ren, Y.; Lu, Y.; Fan, L.; Chang, J.; Ge, Y.; Bao, Z. Estimating irrigation water demand for green spaces in humid areas: Seeking a sustainable water management strategy. Urban Water J. 2017, 15, 16-22. [CrossRef]

20. Nolde, E. Possibilities of rainwater utilisation in densely populated areas including precipitation runoffs from traffic surfaces. Desalination 2007, 215, 1-11. [CrossRef]

21. Chao-Hsien, L.; En-Hao, H.; Yie-Ru, C. Designing a rainwater harvesting system for urban green roof irrigation. Water Supply 2014, 15, 271-277. [CrossRef]

22. Stratigea, D.; Makropoulos, C. Balancing water demand reduction and rainfall runoff minimisation: Modelling green roofs, rainwater harvesting and greywater reuse systems. Water Supply 2015, 15, 248-255. [CrossRef]

23. Charalambous, K.; Bruggeman, A.; Eliades, M.; Camera, C.; Vassiliou, L. Stormwater Retention and Reuse at the Residential Plot Level-Green Roof Experiment and Water Balance Computations for Long-Term Use in Cyprus. Water 2019, 11, 1055. [CrossRef]

24. Sánchez-Reséndiz, J.A.; Ruiz-García, L.; Olivieri, F.; Ventura-Ramos, E. Experimental assessment of the thermal behavior of a living wall system in semi-arid environments of central Mexico. Energy Build. 2018, 174, 31-43. [CrossRef]

25. Barron, N.J.; Deletic, A.; Jung, J.; Fowdar, H.; Chen, Y.; Hatt, B.E. Dual-mode stormwater-greywater biofilters: The impact of alternating water sources on treatment performance. Water Res. 2019, 159, 521-537. [CrossRef] [PubMed]

26. Bustami, R.A.; Belusko, M.; Ward, J.; Beecham, S. Vertical greenery systems: A systematic review of research trends. Build. Environ. 2018, 146, 226-237. [CrossRef]

27. Başdoğan, G.; Çiğ, A. Ecological-Social-Economical Impacts of Vertical Gardens in the Sustainable City Model. Yüzüncü Yıl Üniv. Tartm Bilim. Derg. 2016, 26, 430-438.

28. Cruz, M.; Beckett, R. Bioreceptive design: A novel approach to biodigital materiality. Arq. Arch. Res. Q. 2016, 20, 51-64. [CrossRef]

29. De Jesus, M.P.; Lourenco, J.M.; Arce, R.M.; Macias, M. Green façades and in situ measurements of outdoor building thermal behaviour. Build. Environ. 2017, 119, 11-19. [CrossRef]

30. González-Méndez, B.; Chávez-García, E. Re-thinking the Technosol design for greenery systems: Challenges for the provision of ecosystem services in semiarid and arid cities. J. Arid. Environ. 2020, 179, 104191. [CrossRef]

31. Manso, M.; Castro-Gomes, J. Green wall systems: A review of their characteristics. Renew. Sustain. Energy Rev. $2015,41,863-871$. [CrossRef]

32. Omrany, H.; Ghaffarianhoseini, A.; Ghaffarianhoseini, A.; Raahemifar, K.; Tookey, J. Application of passive wall systems for improving the energy efficiency in buildings: A comprehensive review. Renew. Sustain. Energy Rev. 2016, 62, 1252-1269. [CrossRef]

33. Radić, M.; Dodig, M.B.; Auer, T. Green Facades and Living Walls-A Review Establishing the Classification of Construction Types and Mapping the Benefits. Sustainability 2019, 11, 4579. [CrossRef]

34. Rathnayake, U.; Lau, D.; Chow, C. Review on Energy and Fire Performance of Water Wall Systems as a Green Building Façade. Sustainability 2020, 12, 8713. [CrossRef]

35. Talaei, M.; Mahdavinejad, M.; Azari, R. Thermal and energy performance of algae bioreactive façades: A review. J. Build. Eng. 2020, 28, 101011. [CrossRef]

36. Leong, J.Y.C.; Oh, K.S.; Poh, P.E.; Chong, M.N. Prospects of hybrid rainwater-greywater decentralised system for water recycling and reuse: A review. J. Clean. Prod. 2017, 142, 3014-3027. [CrossRef]

37. Zabidi, H.A.; Goh, H.W.; Chang, C.K.; Chan, N.W.; Zakaria, N.A. A Review of Roof and Pond Rainwater Harvesting Systems for Water Security: The Design, Performance and Way Forward. Water 2020, 12, 3163. [CrossRef]

38. ÖNORM EN 16941-1 On-Site Non-Potable Water Systems_Part 1: Systems for the Use of Rainwater; Austrian Standards Institute: Vienna, Austria, 2018.

39. Riley, B. The state of the art of living walls: Lessons learned. Build. Environ. 2017, 114, 219-232. [CrossRef]

40. Van de Wouw, P.; Ros, E.; Brouwers, H. Precipitation collection and evapo(transpi)ration of living wall systems: A comparative study between a panel system and a planter box system. Build. Environ. 2017, 126, 221-237. [CrossRef] 
41. Mobilia, M.; Longobardi, A.; Sartor, J.F. Including A-Priori Assessment of Actual Evapotranspiration for Green Roof Daily Scale Hydrological Modelling. Water 2017, 9, 72. [CrossRef]

42. Blocken, B.B.; Carmeliet, J.J. Pedestrian Wind Environment around Buildings: Literature Review and Practical Examples. J. Therm. Envel. Build. Sci. 2004, 28, 107-159. [CrossRef]

43. Franco, A.; Cañero, R.F.; Pérez-Urrestarazu, L.; Valera, D. Wind tunnel analysis of artificial substrates used in active living walls for indoor environment conditioning in Mediterranean buildings. Build. Environ. 2012, 51, 370-378. [CrossRef]

44. Pérez, G.; Rincón, L.; Vila, A.; González, J.; Cabeza, L. Behaviour of green facades in Mediterranean Continental climate. Energy Convers. Manag. 2011, 52, 1861-1867. [CrossRef]

45. Chen, L.; Zhang, Z.; Li, Z.; Tang, J.; Caldwell, P.; Zhang, W. Biophysical control of whole tree transpiration under an urban environment in Northern China. J. Hydrol. 2011, 402, 388-400. [CrossRef]

46. Hernández-Santana, V.; David, T.; Martínez-Fernández, J. Environmental and plant-based controls of water use in a Mediterranean oak stand. For. Ecol. Manag. 2008, 255, 3707-3715. [CrossRef]

47. Dingman, S.L. Physical Hydrology, 3rd ed.; Waveland Press: Long Grove, IL, USA, 2015; ISBN 9781478611189.

48. Lee, L.S.; Jim, C. Subtropical summer thermal effects of wirerope climber green walls with different air-gap depths. Build. Environ. 2017, 126, 1-12. [CrossRef]

49. Pérez-Urrestarazu, L.; Egea, G.; Franco-Salas, A.; Fernández-Cañero, R.; Cegarra, G.E. Irrigation Systems Evaluation for Living Walls. J. Irrig. Drain. Eng. 2014, 140, 04013024. [CrossRef]

50. Hoelscher, M. Quantification of Cooling Effects and Water Demand of Urban Facade Greenings; Technical University of Berlin: Berlin, Germany, 2018.

51. Jim, C.; He, H. Estimating heat flux transmission of vertical greenery ecosystem. Ecol. Eng. 2011, 37, 1112-1122. [CrossRef]

52. Mathers, H.; Lowe, S.; Scagel, C.; Struve, D.; Case, L. Abiotic Factors Influencing Root Growth of Woody Nursery Plants in Containers. HortTechnology 2007, 17, 151-162. [CrossRef]

53. Woods Ballard, B.; Wilson, S.; Udale-Clarke, H.; Illman, S.; Scott, T.; Ashley, R.; Kellagher, R. The SUDS Manual; CIRIA: London, UK, 2015; ISBN 978-0-86017-760-9.

54. Kew, B.; Pennypacker, E.; Echols, S. Can Greenwalls Contribute to Stormwater Management? A Study of Cistern Storage Greenwall first Flush Capture. J. Green Build. 2014, 9, 85-99. [CrossRef]

55. Susorova, I.; Angulo, M.; Bahrami, P.; Stephens, B. A model of vegetated exterior facades for evaluation of wall thermal performance. Build. Environ. 2013, 67,1-13. [CrossRef]

56. Farreny, R.; Morales-Pinzón, T.; Guisasola, A.; Tayà, C.; Rieradevall, J.; Gabarrell, X. Roof selection for rainwater harvesting: Quantity and quality assessments in Spain. Water Res. 2011, 45, 3245-3254. [CrossRef] [PubMed]

57. Angrill, S.; Petit-Boix, A.; Morales-Pinzón, T.; Josa, A.; Rieradevall, J.; Gabarrell, X. Urban rainwater runoff quantity and quality-A potential endogenous resource in cities? J. Environ. Manag. 2017, 189, 14-21. [CrossRef]

58. Nehls, T.; Peters, A.; Kraus, F.; Rim, Y.N. Water dynamics at the urban soil-atmosphere interface-rainwater storage in paved surfaces and its dependence on rain event characteristics. J. Soils Sediments 2021, 21, 2025-2034. [CrossRef]

59. Tondera, K.; Blecken, G.-T.; Tournebize, J.; Viklander, M.; Österlund, H.; Wikström, A.A.; Tanner, C.C. Emerging Contaminants: Occurrence, Treatment Efficiency and Accumulation Under Varying Flows. In Ecotechnologies for the Treatment of Variable Stormwater and Wastewater Flows; Springer: Cham, Switzerland, 2018; pp. 93-109. [CrossRef]

60. Barron, N.J.; Hatt, B.; Jung, J.; Chen, Y.; Deletic, A. Seasonal operation of dual-mode biofilters: The influence of plant species on stormwater and greywater treatment. Sci. Total Environ. 2020, 715, 136680. [CrossRef] [PubMed]

61. Simperler, L.; Ertl, T.; Matzinger, A. Spatial Compatibility of Implementing Nature-Based Solutions for Reducing Urban Heat Islands and Stormwater Pollution. Sustainability 2020, 12, 5967. [CrossRef]

62. Angrill, S.; Farreny, R.; Gasol, C.M.; Gabarrell, X.; Viñolas, B.; Josa, A.; Rieradevall, J. Environmental analysis of rainwater harvesting infrastructures in diffuse and compact urban models of Mediterranean climate. Int. J. Life Cycle Assess. 2012, 17, 25-42. [CrossRef]

63. Berlin Senate for Urban Development Communications Rainwater Management Concepts_Greening Buildings, Cooling Buildings; Berlin Senate for Urban Development: Berlin, Germany, 2010.

64. Cheng, C.; Cheung, K.K.; Chu, L. Thermal performance of a vegetated cladding system on facade walls. Build. Environ. 2010, 45, 1779-1787. [CrossRef]

65. Pérez, G.; Coma, J.; Sol, S.; Cabeza, L.F. Green facade for energy savings in buildings: The influence of leaf area index and facade orientation on the shadow effect. Appl. Energy 2017, 187, 424-437. [CrossRef]

66. Besir, A.B.; Cuce, E. Green roofs and facades: A comprehensive review. Renew. Sustain. Energy Rev. 2018, 82, 915-939. [CrossRef]

67. Perini, K.; Bazzocchi, F.; Croci, L.; Magliocco, A.; Cattaneo, E. The use of vertical greening systems to reduce the energy demand for air conditioning. Field monitoring in Mediterranean climate. Energy Build. 2017, 143, 35-42. [CrossRef]

68. Perini, K.; Ottelé, M.; Haas, E.M.; Raiteri, R. Vertical greening systems, a process tree for green façades and living walls. Urban Ecosyst. 2013, 16, 265-277. [CrossRef]

69. Rayner, J.; Raynor, K.; Williams, N. Façade Greening: A Case Study from Melbourne, Australia. Acta Hortic. 2010, 881, 709-713. [CrossRef]

70. Allen, R.G.; Pereira, L.S.; Raes, D.; Smith, M. Crop Evapotranspiration. Guidelines for Computing Crop Water Requirements-FAO Irrigation and Drainage Paper 56; Food and Agriculture Organization of the United Nations: Rome, Italy, 1998 ; ISBN 9251042195. 
71. Marasco, D. Alternative Metrics of Green Roof Hydrologic Performance: Evapotranspiration and Peak Flow Reduction; Columbia University: New York, NY, USA, 2014.

72. Priestley, C.H.B.; Taylor, R.J. On the Assessment of Surface Heat Flux and Evaporation Using Large-Scale Parameters. Mon. Weather Rev. 1972, 100, 81-92. [CrossRef]

73. Rozos, E.; Makropoulos, C.; Maksimović, Č. Rethinking urban areas: An example of an integrated blue-green approach. Water Supply 2013, 13, 1534-1542. [CrossRef]

74. Herrera, J.; Bonilla, C.A.; Castro, L.; Vera, S.; Reyes, R.; Gironás, J. A model for simulating the performance and irrigation of green stormwater facilities at residential scales in semiarid and Mediterranean regions. Environ. Model. Softw. 2017, 95, 246-257. [CrossRef]

75. Schmidt, M. Energy and Water, a Decentralized Approach to an Integrated Sustainable Urban Development. 2000, pp. 1-6. Available online: http:/ / citeseerx.ist.psu.edu/viewdoc/download?doi=10.1.1.1071.561\&rep=rep1\&type=pdf (accessed on 20 January 2021).

76. Koumoudis, S. Green Wall Planting Module, Support Structure and Irrigation Control System. U.S. Patent No. 7,926,224, 7 September 2010.

77. Roehr, D.; Laurenz, J. Living skins: Environmental benefits of green envelopes in the city context. WIT Trans. Ecol. Environ. 2008, 113, 149-158. [CrossRef]

78. Natarajan, M.; Rahimi, M.; Sen, S.; Mackenzie, N.; Imanbayev, Y. Living wall systems: Evaluating life-cycle energy, water and carbon impacts. Urban Ecosyst. 2015, 18, 1-11. [CrossRef]

79. Lau, J.T.; Mah, D.Y.S. Green Wall for Retention of Stormwater. Pertanika J. Sci. Technol. 2018, 26, $283-298$.

80. Tiwary, A.; Godsmark, K.; Smethurst, J. Field evaluation of precipitation interception potential of green façades. Ecol. Eng. 2018, 122, 69-75. [CrossRef] 